\title{
Preparation of V-4Cr-4Ti Alloys from Mixed Oxides via Electro-Deoxidation Process in Molten Salt
}

\author{
Xiaozhou Cao ${ }^{1}$, Qiuyue $\mathrm{Li}^{1}$, Yuanyuan $\mathrm{Shi}^{2}$, Dong $\mathrm{Wu}^{3}$ and Xiangxin Xue ${ }^{1, *}$ \\ 1 School of Metallurgy, Northeastern University, Shenyang 110819, China; caoxz@smm.neu.edu.cn (X.C.); \\ liqyue163@163.com (Q.L.) \\ 2 Institute of Metal Research, Chinese Academy of Sciences, Shenyang 110016, China; yyshi@imr.ac.cn \\ 3 Chinalco Shenyang Non-ferrous Metal Processing Co., Ltd., Shenyang 110108, China; voa121@163.com \\ * Correspondence: xuexx@mail.neu.edu.cn; Tel.: +86-13909813905
}

Received: 3 July 2020; Accepted: 5 August 2020; Published: 7 August 2020

check for updates

\begin{abstract}
V-4Cr-4Ti alloys exhibit important advantages as a candidate structural materials for fusion reactor first-walls and blanket applications. $\mathrm{V}-4 \mathrm{Cr}-4 \mathrm{Ti}$ alloys were prepared by direct electrochemical reduction of the solid mixture of $\mathrm{V}_{2} \mathrm{O}_{3}, \mathrm{Cr}_{2} \mathrm{O}_{3}$ and $\mathrm{TiO}_{2}$ in the molten $\mathrm{CaCl}_{2}-\mathrm{NaCl}$ eutectic at $1073 \mathrm{~K}$. The influence of cell voltage, sintering temperature and electrolysis time on the electrolysis process are reported. The microstructure and phase compositions of the products were analyzed by scanning electron microscopy (SEM) and X-ray diffraction (XRD) during the electrolysis process. The results showed that $\mathrm{V}-4 \mathrm{Cr}-4 \mathrm{Ti}$ alloys can be obtained at the voltage of $3.1 \mathrm{~V}$ and the time of $0.5 \mathrm{~h} . \mathrm{Cr}_{2} \mathrm{O}_{3}$ was first reduced to $\mathrm{Cr}$ metal, while $\mathrm{V}_{2} \mathrm{O}_{3}$ and $\mathrm{TiO}_{2}$ was reduced to low-valence oxide of vanadium and titanium. The reduction rate increases with increasing cell voltage, with much perovskite oxide formed during the electrolysis process.
\end{abstract}

Keywords: V-4Cr-4Ti; fusion reactor; electrochemistry; electro-deoxidation; molten salt

\section{Introduction}

The next step in the worldwide fusion program is the construction of a fusion experiment-international thermonuclear experimental reactor (ITER)—with a burning reactor-scale D-T plasma. High-performance structural materials will be critical for the future success of proposed fusion energy reactors due to the complexity of the operational conditions, including the simultaneous influence of thermal, particle and high energy neutron fluxes [1].

The $\mathrm{V}-4 \mathrm{Cr}-4 \mathrm{Ti}$ alloy is considered a promising structure material in nuclear fusion reactors due to its impressive mechanical properties at high temperature, chemical compatibility with liquid lithium, good creep resistance, high thermal stress factor and low activation property [2-4]. Vanadium alloy is also widely used in the fields of metallurgy, aerospace, electronics, information, marine and chemical industry.

Vanadium alloys have been produced by various methods, including vacuum melting and thermal reduction [5-7]. Typically, in the industrial scale production of V-Cr-Ti alloys, first, $\mathrm{V}$ and $\mathrm{Ti}$ are produced via a pyrometallurgical process involving the chlorination of the $\mathrm{V}$ and Ti oxides to form chlorides and reduced by high purity $\mathrm{Mg}$ know as the Kroll process [8]. Cr is produced via an aluminothermy reduction process using Cr oxide known as the Goldschmidt process [9]. Then, the pure metals are fused together under vacuum by melting, alloying and casting. These methods involve high energy consumption, severe pollution and long process from the extraction of raw materials to the product, all of which constrain its wide applications in various fields.

Chen et al. proposed a new process to produce the parent metals and alloys by direct electro-deoxidation of metallic oxides and their mixtures in molten salts in one operational step. 
The technology has been demonstrated a simple and environmentally friendly way compared with the conventional metallurgical routes [10].

Many alloys ( $\mathrm{Ni}_{2} \mathrm{MnGa}, \mathrm{CeNi}_{4} \mathrm{Cu}$, Ti-6Al-4 V, Ti-V-Cr, Ni-35Ti-15Hf, U-40Pu-5Np) [11-16] have been prepared in this way. The method to prepare $\mathrm{V}-4 \mathrm{Cr}-4 \mathrm{Ti}$ alloy is a clean, energy efficient, low cost and affordable process.

In the present study, the electrochemical reduction mechanism of $\mathrm{V}_{2} \mathrm{O}_{3}-\mathrm{Cr} 2 \mathrm{O} 3-\mathrm{TiO}_{2}$ mixture in molten salt was investigated based on the cyclic voltammetry to clarify the reduction pathway and reduction order of mixture. The influences of cell voltage and time on the phase composition and morphologies of final electrolytic products were performed to obtain the optimal synthetic parameter to control the electrolysis process of $\mathrm{V}-4 \mathrm{Cr}-4 \mathrm{Ti}$.

\section{Experimental Procedure}

Commercial $\mathrm{V}_{2} \mathrm{O}_{3}$ powders ( $\geq 99 \mathrm{wt} \%$, average particle size less than $50 \mu \mathrm{m}$ ), $\mathrm{Cr}_{2} \mathrm{O}_{3}$ powders ( $\geq 99 \mathrm{wt} \%$, average particle size less than $50 \mu \mathrm{m}$ ) and $\mathrm{TiO}_{2}$ powders $(\geq 99 \mathrm{wt} \%$, average particle size less than $50 \mu \mathrm{m}$ ) were used as the starting materials. The mixtures were mixed by ball-milling in a polyurethane jar for $12 \mathrm{~h}$. Following drying, the mixtures were uniaxially cold-pressed in a stainless steel die at a pressure of $100 \mathrm{Mpa}$. The green compacts (15 $\mathrm{mm}$ in diameter and $2 \mathrm{~mm}$ in thickness) were sintered under vacuum at $1373 \mathrm{~K}$ for $2 \mathrm{~h}$ in a furnace.

The $\mathrm{V}_{2} \mathrm{O}_{3}-\mathrm{Cr} 2 \mathrm{O} 3-\mathrm{TiO}_{2}$-sintered sample - wrapped with Mo wire-was used as cathode connected with Mo rod (2 $\mathrm{mm}$ in diameter) as current collector, and a graphite rod was used as an anode. The alumina crucible was filled with the mixture of $\mathrm{CaCl}_{2}$ and $\mathrm{NaCl}$ and placed in a stainless steel tube reactor in a furnace. The whole electrolysis process was carried out under argon gas. $\mathrm{CaCl}_{2}$ and $\mathrm{NaCl}$ were dried under vacuum at $673 \mathrm{~K}$ for $72 \mathrm{~h}$ to remove residual water before use. In order to remove the impurities in the $\mathrm{CaCl}_{2}-\mathrm{NaCl}$ melt, pre-electrolysis was carried out at $3.0 \mathrm{~V}$ for $2 \mathrm{~h}$ at $1073 \mathrm{~K}$. Graphite rods (10 $\mathrm{mm}$ in diameter) were used as anode and cathode during pre-electrolysis process. After the electro-deoxidation experiment, the cathode product was removed from the melt and cooled to room temperature. Then, the product was crushed and washed with distilled water to remove the molten salt and dried at $353 \mathrm{~K}$ for $2 \mathrm{~h}$ for analysis. The phase composition and microstructure of sintered samples and products were determined using a Philips MRD 1800 (Almelo, Netherlands) X-ray diffraction (XRD) and scanning electron microscope (SEM, Zeiss Ultra, Oberkochen, Germany) in combination with energy dispersive X-ray spectroscopy (EDX), respectively.

Cyclic voltammetry (CV) measurements were performed in a three-electrode electrochemical cell using a potentiostat Solartron 1287A electrochemical system controlled by CorrWare software (Farnborough, UK). The mixture of $\mathrm{V}_{2} \mathrm{O}_{3}-\mathrm{Cr} 2 \mathrm{O} 3-\mathrm{TiO}_{2}$ was used as the working electrode (WE). The graphite crucible containing molten salt was used as the counter electrode (CE). A Pt wire (1 mm in diameter) was used as the reference electrode (RE).

\section{Results and Discussion}

\subsection{Phase Composition and Microstructure}

The XRD patterns of the oxide mixture after sintering at $1373 \mathrm{~K}$ for $2 \mathrm{~h}$ are shown in Figure 1. The patterns of the product exhibit the diffraction peaks of $\mathrm{V}_{2} \mathrm{O}_{3}$ and $\mathrm{TiO}_{2}$. The peaks of $\mathrm{Cr}_{2} \mathrm{O}_{3}$ were not detected, which may be because the amount of $\mathrm{Cr}_{2} \mathrm{O}_{3}$ was too little and did not reach the detection limit of equipment-or that since $\mathrm{V}_{2} \mathrm{O}_{3}$ and $\mathrm{Cr}_{2} \mathrm{O}_{3}$ have a similar atomic size, chemical affinity and crystal structure, $\mathrm{V}_{2} \mathrm{O}_{3}$ and $\mathrm{Cr}_{2} \mathrm{O}_{3}$ may have formed a continuous solid solution. 


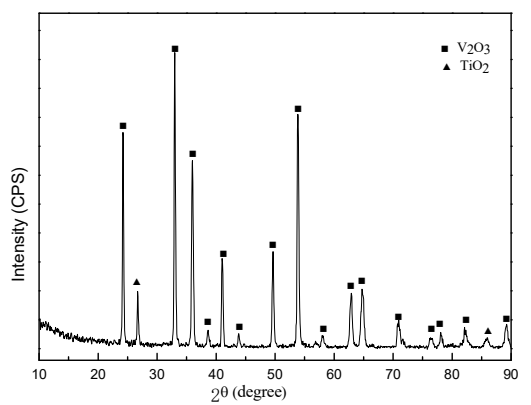

Figure 1. XRD patterns of the oxide mixture after sintering at $1373 \mathrm{~K}$ for $2 \mathrm{~h}$.

Figure 2 shows the SEM image and the elements $(\mathrm{V}, \mathrm{Cr}, \mathrm{Ti}, \mathrm{O})$ distribution of the sintered sample. As can be seen from Figure $2 \mathrm{~b}-\mathrm{e}$, the elements $(\mathrm{V}, \mathrm{Cr}, \mathrm{Ti}, \mathrm{O})$ are distributed uniformly in the sample and there is no significant aggregation which is beneficial to form homogeneous alloys during the electrolysis process.

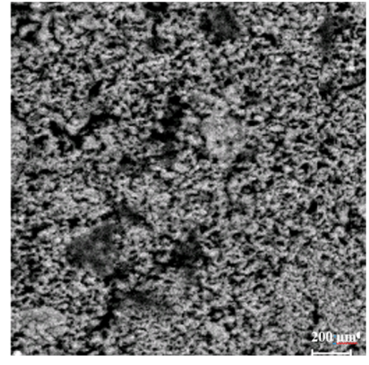

(a)

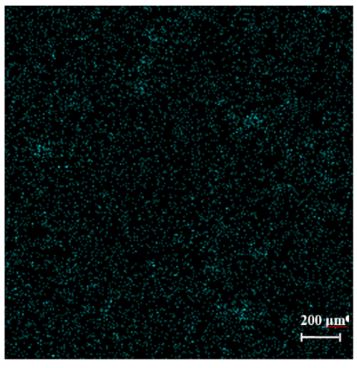

(d)

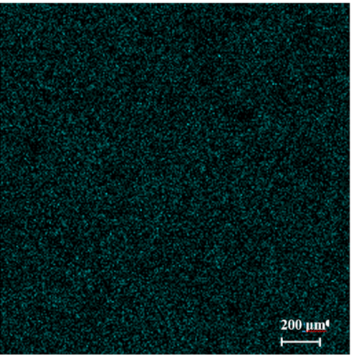

(b)

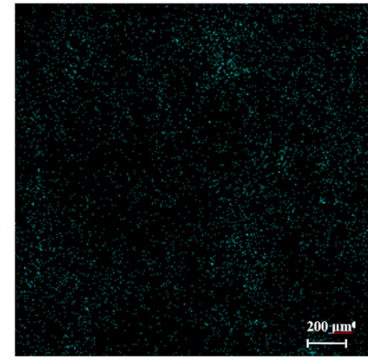

(c)

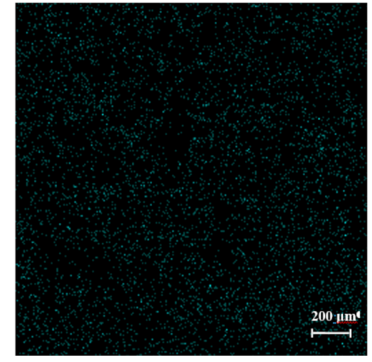

(e)

Figure 2. SEM micrograph of sintered sample with element distribution. (a) micrograph; (b) V distribution; (c) Cr distribution; (d) Ti distribution; (e) O distribution.

It can be seen in Figure 2a that the particle size in the sintered samples is in the micrometer range. There are many interconnected open pores in the samples which can provide good ion transport channels during electrolysis process to reduce the oxygen ion migration resistance and enter into the molten salt rapidly, which can improve current efficiency [17].

\subsection{The Effect of Electrolysis Time}

Figure 3 shows the XRD patterns of the products reduced for $10 \mathrm{~min}, 30 \mathrm{~min}, 60 \mathrm{~min}$ and $120 \mathrm{~min}$. $\mathrm{V}_{2} \mathrm{O}_{3}$ and low-valence vanadium oxide $\mathrm{V}_{14} \mathrm{O}_{6}$ are the dominant phase after 10 min of electrolysis which means $\mathrm{V}_{2} \mathrm{O}_{3}$ was reduced on the surface of cathode. Meanwhile, the peak of $\mathrm{Cr}$ was detected in the products and $\mathrm{Cr}_{2} \mathrm{O}_{3}$ was reduced to metal $\mathrm{Cr}$ in the oxide mixture first. 


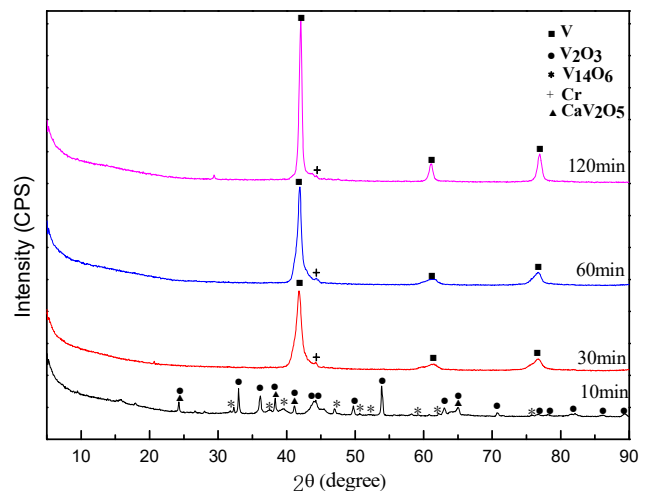

Figure 3. XRD patterns of the products electro-deoxidized in $\mathrm{CaCl}_{2}-\mathrm{NaCl}$ melt at different time.

Figure 4a shows the microstructure of the product surface after $10 \mathrm{~min}$ of electrolysis. The particles size is not uniform, and the product layer is dense-probably due to the incomplete reduction of the samples. According to the EDX analysis in Table 1, Ca and $\mathrm{O}$ were detected. At the beginning of electrolysis, the content of $\mathrm{O}$ and $\mathrm{Ca}$ was higher, which means much oxide was not reduced. Ca ions migrate from molten salt to the surface of cathode at electric field and react with the component of cathode [18]. $\mathrm{CaV}_{2} \mathrm{O}_{5}$ was detected -as seen in Figure 3-which means the calcium-enriched oxides are thermodynamically more stable than the corresponding metal oxides. The calcium-enriched oxides were detected in the cases of the electro-deoxidation process solid oxides such as $\mathrm{Ta}_{2} \mathrm{O}_{5}, \mathrm{ZrO}_{2}, \mathrm{TiO}_{2}$, $\mathrm{Al}_{2} \mathrm{O}_{3}$ in molten $\mathrm{CaCl}_{2}$ molten salt [19].

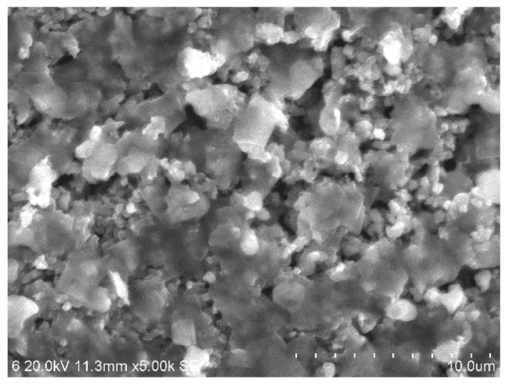

(a)

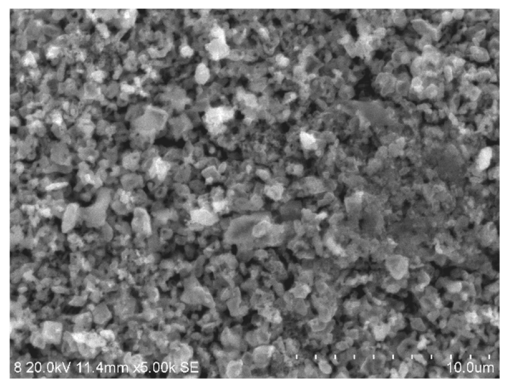

(c)

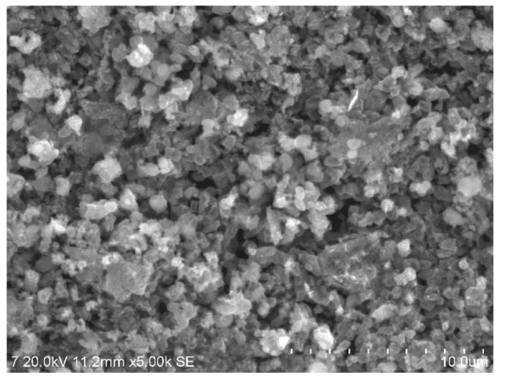

(b)

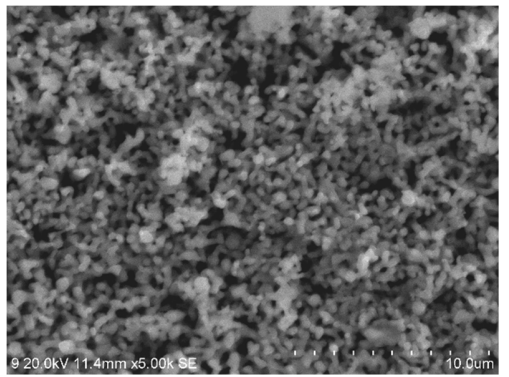

(d)

Figure 4. SEM micrographs of products electro-deoxidized in $\mathrm{CaCl}_{2}-\mathrm{NaCl}$ melt at different times. (a) $10 \mathrm{~min}$; (b) $30 \mathrm{~min}$; (c) $60 \mathrm{~min}$; (d) $120 \mathrm{~min}$.

Table 1. Element content of product at different electrolysis time (\%).

\begin{tabular}{ccccc}
\hline Time & $\mathbf{1 0} \mathbf{~ m i n}$ & $\mathbf{3 0} \mathbf{~ m i n}$ & $\mathbf{6 0} \mathbf{~ m i n}$ & $\mathbf{1 2 0} \mathbf{~}$ in \\
\hline $\mathrm{O}$ & 26.81 & 14.1 & 2.75 & - \\
$\mathrm{Ca}$ & 7.96 & 2.4 & 1.35 & - \\
\hline
\end{tabular}


The major phase is metal $\mathrm{V}$. The minor phase is metal $\mathrm{Cr}$ after $30 \mathrm{~min}$ of electrolysis; no oxide or low-valence oxide were detected in the product, as shown in Figure 3. The diffracted intensity of metal $\mathrm{V}$ increased and sharpened with the prolonged electrolysis time from $60 \mathrm{~min}$ to $120 \mathrm{~min}$, as the content of $\mathrm{O}$ and $\mathrm{Ca}$ decreases. As the electrolysis time grew longer, the reduction reaction was carried out more completely. The diffraction peak of metal $\mathrm{V}$ shifted because the fine grain size may have been because the solid solubility of $\mathrm{Ti}$ in $\mathrm{V}$ increased, causing the change of lattice constant and interplanar spacing.

As seen from Figure $4 a-d$, the microstructure of the product changed regularly with the increase of electrolysis time. The mixture oxides were reduced into metal, the particles size of new generated product decreased and the shape became uniform. The particles size was less than $1 \mu \mathrm{m}$ after $120 \mathrm{~min}$ of electrolysis as shown in Figure 4d with many connected pores, which attribute to the oxygen ions migrate to the molten salt from mixed oxides. The alloy consisted of the interconnected nodular shape particles, in which the ratio (weight percent) of $\mathrm{V}, \mathrm{Cr}$, $\mathrm{Ti}$ is $91.88 \%, 2.94 \%$ and $5.08 \%$, the composition was very close to the target alloy 92:4:4 determined by the EDX analysis with the correspond SEM image.

\subsection{The Effect of Electrolysis Voltage}

Figure 5 shows the current-time plots at different electrolysis voltages in $\mathrm{CaCl}_{2}-\mathrm{NaCl}$ melt at $1073 \mathrm{~K}$. Current change trend of the curves were similar. At the very beginning, the current reached the maximum value which was related to the rapid reduction of surface layer of the oxide mixture cathode. The reaction took place between the sample and the current collector, which had large reaction regions. After the initial period, the reaction from the surface to the inner of the samples, the current decreased rapidly which attributed to the increase of resistance [20]. There was a short plateau at 1.0 A, after which the reduction current tended to be constant and was under the control of oxygen ions diffusion. After $60 \mathrm{~min}$ of electrolysis, the current decreased to the background value and remained at a steady state.

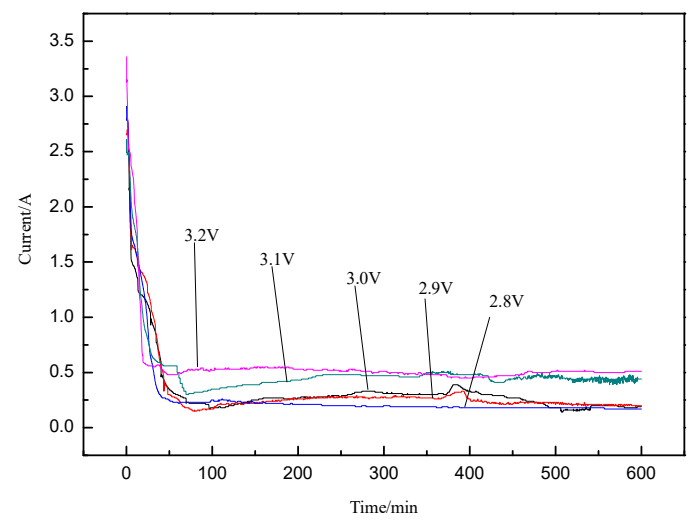

Figure 5. Current-time plots of electro-deoxidation oxide mixture at different voltage.

The current increased evidently with an increase of electrolysis voltage at the whole electrolysis process. With the increase of the voltage, electrochemical reduction rate increased on the surface of electrode, the current rapidly decreased, and finally reach a stable value at a short time, which was beneficial to accelerate the transferring of oxygen ions. A higher voltage could improve the oxygen ions migration rate. At the same time, the secondary reaction are also accelerated which lead to the current is higher at $3.2 \mathrm{~V}$.

\subsection{Cyclic Voltammetry}

Figure 6 shows a typical cyclic voltammetry $(\mathrm{CV})$ curve of the $\mathrm{V}_{2} \mathrm{O}_{3}-\mathrm{Cr} 2 \mathrm{O} 3-\mathrm{TiO}_{2}$ in molten $\mathrm{CaCl}_{2}-\mathrm{NaCl}$ at $1073 \mathrm{~K}$. There are five well-defined reduction peaks ( $\left.\mathrm{c} 1, \mathrm{c} 2, \mathrm{c3}, \mathrm{c4}, \mathrm{c5}\right)$. The reduction current increases continuously to the maximum value, the reduction peak c5 at $-1.5 \mathrm{~V}$ which can be 
attributed the reduction of the calcium cations to the calcium metal onto the working electrode. The four reduction peaks (c1, c2, c3, c4) potential are more positive than the calcium metal deposition, which indicated that there are four electrochemical reduction processes of $\mathrm{V}_{2} \mathrm{O}_{3}-\mathrm{Cr} 2 \mathrm{O} 3-\mathrm{TiO}_{2}$ to form $\mathrm{VCrTi}$. The XRD and EDX analysis results have confirmed that low-valence oxides and intermediate product perovskite formed during the electrochemical reduction of oxide mixtures [21]. Hence, we proposed the possible reaction of $\mathrm{V}_{2} \mathrm{O}_{3}-\mathrm{Cr} 2 \mathrm{O} 3-\mathrm{TiO}_{2}$ in $\mathrm{CaCl}_{2}-\mathrm{NaCl}$. The following electrode reaction (1)-(6) may be associated with the four reduction peaks.

$$
\begin{gathered}
\mathrm{Cr}_{2} \mathrm{O}_{3}+6 \mathrm{e}=2 \mathrm{Cr}+3 \mathrm{O}^{2-} \\
8 \mathrm{~V}_{2} \mathrm{O}_{3}+2 \mathrm{Ca}^{2+}+28 \mathrm{e}=\mathrm{CaV}_{2} \mathrm{O}_{5}+\mathrm{V}_{14} \mathrm{O}_{6}+13 \mathrm{O}^{2-} \\
\mathrm{xTiO}_{2}+2(2 \mathrm{x}-1) \mathrm{e}=\mathrm{Ti}_{\mathrm{x}} \mathrm{O}+(2 \mathrm{x}-1) \mathrm{O}^{2-} \\
\mathrm{Ti}_{\mathrm{x}} \mathrm{O}+2 \mathrm{e}=\mathrm{xTi}+\mathrm{O}^{2-} \\
\mathrm{CaV}_{2} \mathrm{O}_{5}+8 \mathrm{e}=2 \mathrm{~V}+\mathrm{Ca}^{2+}+5 \mathrm{O}^{2-} \\
\mathrm{V}_{14} \mathrm{O}_{6}+14 \mathrm{Ti}+14 \mathrm{Cr}+6 \mathrm{e}=14 \mathrm{VCrTi}+3 \mathrm{O}^{2-}
\end{gathered}
$$

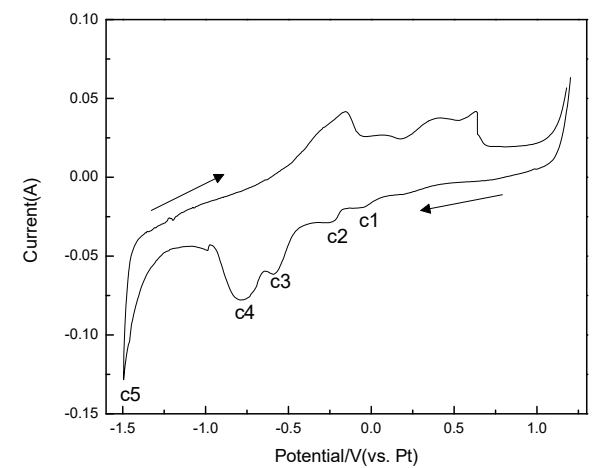

Figure 6. $\mathrm{CV}$ of $\mathrm{V}_{2} \mathrm{O}_{3}-\mathrm{Cr} 2 \mathrm{O} 3-\mathrm{TiO}_{2}$ in molten $\mathrm{CaCl}_{2}-\mathrm{NaCl}$ at $1073 \mathrm{~K}$ and scan rate $50 \mathrm{mV} / \mathrm{s}$.

It is worth mentioning that various $\mathrm{Ca}_{\mathrm{x}} \mathrm{TiO}_{\mathrm{y}}$ and low valence $\mathrm{Ti}_{\mathrm{x}} \mathrm{O}$ phases were detected in electrolysis of $\mathrm{TiO}_{2}$ pellet [22], while the perovskite was not detected in this experiment in Figure 3 due to the amount is little.

\section{Conclusions}

$\mathrm{V}-4 \mathrm{Cr}-4 \mathrm{Ti}$ alloys were produced by the direct reduction of mixtures of $\mathrm{V}_{2} \mathrm{O}_{3}-\mathrm{Cr} 2 \mathrm{O} 3-\mathrm{TiO}_{2}$ in molten salts. Electrochemical reduction rate increased with the increase of electrolysis voltage. With the time prolonging the electrochemical reaction carries out more completely from the surface of cathode to its interior and from high-valence to low-valence oxide until to metal and alloy. During the electrochemical reduction $\mathrm{Cr}_{2} \mathrm{O}_{3}$ can be reduced to $\mathrm{Cr}$ first, then perovskite and low-valence oxide was reduced to $\mathrm{V}$ and $\mathrm{Ti}$ and finally formed $\mathrm{V}-4 \mathrm{Cr}-4 \mathrm{Ti}$ alloys.

Author Contributions: Investigation, X.C. and Q.L.; data curation, Y.S.; resources, D.W.; writing-review and editing, X.C.; supervision, X.X.; All authors have read and agreed to the published version of the manuscript.

Funding: This research was funded by Natural Science Foundation of China, Grant Number 51204043.

Conflicts of Interest: The authors declare no conflict of interest. 


\section{References}

1. Barabash, V.; Federici, G.; Linke, J.; Wu, C.H. Material/plasma surface interaction issues following neutron damage. J. Nucl. Mater. 2003, 313-316, 42-51. [CrossRef]

2. Marion, L.F.; Jean-Marie, G.; Pierre, W. Assessment of European V-4Cr-4Ti alloy-CEA-J57. J. Nucl. Mater. 2013, 442, 325-329.

3. Li, Z.D.; Cui, S.; Lin, C.G. Current Research State and Prospects of V-Cr-Ti Alloys Designing for Fusion Applications. Chin. J. Rare Met. 2007, 31, 840-846.

4. Sato, S.; Tanaka, T.; Hori, J. Radioactivity of the vanadium alloy induced by D-T neutron irradiation. J. Nucl. Mater. 2004, 329, 1648-1652. [CrossRef]

5. Mukherjee, A.; Krishnamurthy, N. Phase evolution during mechanochemical coreduction of $\mathrm{V}_{2} \mathrm{O}_{5}$ and $\mathrm{TiO}_{2}$ with Al. Int. J. Self-Propag. High-Temp. Synth. 2010, 19, 237-243. [CrossRef]

6. Kaneko, Y.; Kojima, H. Synthesis and electrical conductivity of vanadium bronzes by molten salt electrolysis. Solid State Ion. 1991, 49, 167-173. [CrossRef]

7. Li, Y.F.; Luo, C.; Wang, Z.G.; Ren, D.P.; Jia, J.Y. Microstructure of V-4Cr-4Ti alloy fabricated by vacuum arc remelting of consumable electrode. T. Nonferr. Metal. Soc. 2008, 18, 805-811.

8. Suzuki, R.O.; Tatemoto, K.; Kitagawa, H. Direct synthesis of the hydrogen storage V-Ti alloy powder from the oxides by calcium co-reduction. J. Alloy. Compunds 2004, 285, 173-180. [CrossRef]

9. Hyslop, D.J.S.; Abdelkader, A.M.; Cox, A.; Fray, D.J. Electrochemical synthesis of a biomedically important Co-Cr alloy. Acta Mater. 2010, 58, 3124-3130. [CrossRef]

10. Chen, G.Z.; Fray, D.J.; Farthing, T.W. Direct electrochemical reduction of titanium dioxide to titanium in molten calcium chloride. Nature 2000, 407, 361-364. [CrossRef]

11. Muir Wood, A.J.; Copcutt, R.C.; Chen, G.Z.; Fray, D.J. Electrochemical Fabrication of Nickel Manganese Gallium Alloy Powder. Adv. Eng. Mater. 2003, 5, 650-653. [CrossRef]

12. Kang, X.; Xu, Q.; Yang, X.M.; Song, Q.S. Electrochemical synthesis of $\mathrm{CeNi}_{4} \mathrm{Cu}$ alloy from the mixed oxides and in situ heat treatment in a eutectic LiCl-KCl melt. Mater. Lett. 2010, 64, 2258-2260. [CrossRef]

13. Sakai, H.; Oka, Y.; Suzuki, R.O. Synthesis of Ti-6Al-4V Alloy by the Electrolysis of Molten $\mathrm{CaCl}_{2}-\mathrm{CaO}$. J. Jpn. Inst. Met. 2008, 72, 921-927. [CrossRef]

14. Kano, Y.; Suzuki, R.O. Preparation of Hydrogen Storage Ti-V-Cr Alloy from the Oxide Mixture in $\mathrm{CaCl}_{2}$. Ti-2007 Science and Technology. In Proceedings of the 11th World Conference on Titanium, Kyoto, Japan, 3-7 June 2007; pp. 107-110.

15. Wang, B.H.; Bhagat, T.; Lan, X.Z.; Dashwood, R.J. Production of Ni-35Ti-15Hf Alloy via the FFC Cambridge Process. J. Electrochem. Soc. 2011, 158, 595-602. [CrossRef]

16. Lizuka, M.; Sakamura, Y.; Inoue, T. Electrochemical reduction of (U-40Pu-5Np) $\mathrm{O}_{2}$ in molten LiCl electrolyte. J. Nucl. Mater. 2006, 359, 102-113.

17. Abderlkader, A.M.; Fray, D.J. Direct electrochemical preparation of Nb-10Hf-1Ti alloy. Electrochim. Acta 2010, 55, 2924-2931. [CrossRef]

18. Benson, L.L.; Mellor, I.; Jackson, M. Direct reduction of synthetic rutile using the FFC process to produce low-cost novel titanium alloys. J. Mater. Sci. 2016, 51, 4150-4261. [CrossRef]

19. Abdelkader, A.M.; Tripuraneni, K.; Cox, A.; Fray, D.J. DC voltammetry of electro-deoxidation of solid oxides. Chem. Rev. 2013, 11, 2863-2886. [CrossRef]

20. Gordo, E.; Chen, G.Z.; Fray, D.J. Toward optimisation of electrolytic reduction of solid chromium oxide to chromium powder in molten chloride salts. Electrochi. Acta 2004, 49, 2195-2208. [CrossRef]

21. Mukherjee, A.; Dyck, J.V.; Guo, M.X. GSLM study on the interaction of $\mathrm{Nd}_{2} \mathrm{O}_{3}$ with $\mathrm{CaCl}_{2}$ and $\mathrm{CaF}_{2}-\mathrm{LiF}$ molten melts. J. Mater. Sci. 2017, 52, 1717-1726. [CrossRef]

22. Xiao, W.; Wang, D.H. The electrochemical reduction processes of solid compounds in high temperature molten salts. Chem. Soc. Rev. 2014, 43, 3215-3228. [CrossRef] [PubMed]

(C) 2020 by the authors. Licensee MDPI, Basel, Switzerland. This article is an open access article distributed under the terms and conditions of the Creative Commons Attribution (CC BY) license (http://creativecommons.org/licenses/by/4.0/). 